\section{Rapid and Gentle Method for the Isolation of DNA from Nuclear Poly- hedrosis Viruses}

BioTechniques 20:364-368 (March 1996)

The baculoviruses are a large family of double-stranded DNA viruses that infect holometabolous insects (4). They are now widely used as eukaryotic expression vectors and as biopesticides. Use of baculoviruses for the expression of foreign genes requires the isolation of pure viral DNA for transfection in permissive insect cell lines. The genotypic identity of a baculovirus is also a prerequisite for its use as a biopesticide and in molecular studies. Several methods such as characterization of viral proteins by polyacrylamide gel electrophoresis, enzyme-linked immunosorbent assay (ELISA), serological characterization and biochemical identification of nucleic acids have been investigated (3), but restriction enzyme digestion patterns of the viral DNA is the most sensitive and reliable method for this purpose because no two clones of viruses have the same restriction endonuclease band pattern (9).

Baculovirus DNA from polyhedra is usually isolated from occluded virus after dissolving the polyhedra either in dilute alkali, followed by isolation of polyhedra-derived virus (PDV), or directly in strong alkali (7). The yield of viral DNA is poor when dilute alkali is used, and the DNA isolated by using strong alkali often renders it unsuitable for transfection. This requires extensive dialysis to make the DNA pure for restriction enzyme digestion and for transfection.

Uses of chaotropic agents like guanidine hydrochloride and guanidinium isothiocyanate (GIT) in isolating nucleic acids from different organisms and even tissues rich in nucleases are well documented. Earlier we described a procedure for rapid isolation of pure plasmid and phage DNA using GIT (2). Viral DNA isolated by using chaotropic agents alone $(5,6)$ requires extensive dialysis to ensure purity for restriction enzyme digestion. Here we describe a simple and rapid procedure for the direct isolation of pure nuclear poly-

Table 1. Comparison of Tissue Culture Infectious Dose ${ }_{50}\left(\operatorname{TCID}_{50}\right)$ and pfu/mL of the Extracellular Virus (ECV) Generated by Transfection of $1 \mu \mathrm{g}$ of Viral DNA Isolated by the GIT Method (1) and by CsCl-Ethidium Bromide Gradient Centrifugation (2)

\begin{tabular}{|lccc|}
\hline $\begin{array}{c}\text { DNA Isolation } \\
\text { Method }\end{array}$ & $\begin{array}{c}\text { Amount of } \\
\text { DNA Used }\end{array}$ & TCID $_{\mathbf{5 0}}$ & pfu/mL \\
\hline By GIT & $1 \mu \mathrm{g}$ & $10^{-6.536}$ & $2.4 \times 10^{8}$ \\
CsCl, EtdBr- & $1 \mu \mathrm{g}$ & $10^{-5.5}$ & $3.2 \times 10^{7}$ \\
purified DNA & & & \\
\hline
\end{tabular}

hedrosis virus (NPV) DNA from polyhedra and extracellular virus (ECV) using GIT in combination with ammonium acetate.

Autographa californica NPV (AcNPV) E 2 (obtained from Max. D. Summers, Texas A \& M University) was propagated by infecting and transfecting Spodoptera frugiperda IPLB-Sf-21 $\mathrm{AE}$ or Sf9 cells maintained at $27^{\circ} \mathrm{C}$ in TNM-FH medium (Sigma Chemical, St. Louis, MO, USA), supplemented with $10 \%$ fetal calf serum (Life Technologies, Gaithersburg, MD, USA) as described by Summers and Smith (10). Virus derived from Spodoptera litura (SINPV) was propagated in the larvae of $S$. litura by the standard method (8).

Tissue culture dishes were seeded with $1 \times 10^{6}$ cells in a final volume of 2 $\mathrm{mL}$ of complete medium and incubated at $27^{\circ} \mathrm{C}$ for $1 \mathrm{~h}$ to allow the cells to attach. The medium was then aspirated out and the viral inoculum, 0.1 plaqueforming units (pfu) per cell, was added to the cell monolayer. After $1 \mathrm{~h}$, the medium was replaced by fresh medium and was again incubated at $27^{\circ} \mathrm{C}$.

The ECV was isolated from $48-\mathrm{h}$ post-infected culture. The medium was first centrifuged at $4000 \times g$ for $10 \mathrm{~min}$ at $4^{\circ} \mathrm{C}$ in Beckman Instruments GS-6R low-speed centrifuge (Fullerton, CA, USA). The supernatant was further centrifuged at $34000 \mathrm{rpm}$ at $4^{\circ} \mathrm{C}$ for 75 min in a Beckman Instruments ultracentrifuge using a VTi 50 rotor to pellet the virus.

Occluded virus (OV) was isolated from a 6-day-old infected culture. The cells were scraped out of the culture plate using a rubber policeman and homogenized in a Potter Elvehjem homogenizer (New York, NY, USA) (glass-glass, Piston B) in $0.1 \%$ (wt/vol) sodium dodecyl sulfate (Sigma Chemical), and the polyhedra were pelleted by centrifugation for $2-3 \mathrm{~min}$ at 12000 $\mathrm{rpm}$ in a microcentrifuge. The pelleted polyhedra were washed with distilled water and then with acetone by centrifugation. The pellet was finally airdried and stored at $-20^{\circ} \mathrm{C}$.

Occluded SINPV from infected dead larvae of $S$. litura was isolated af-

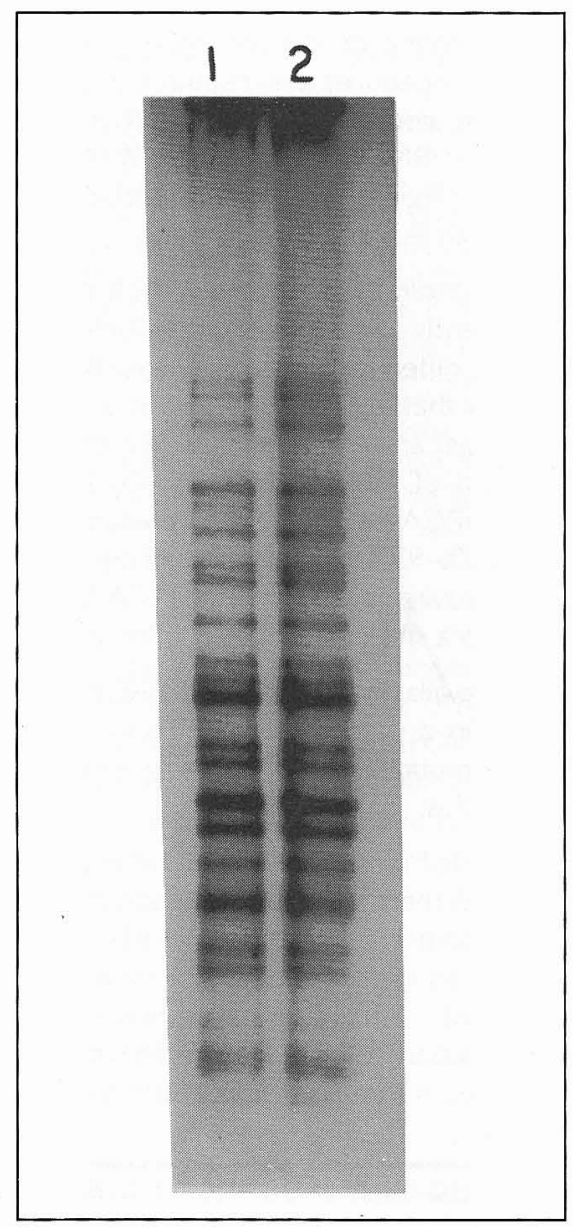

Figure 1. Restriction endonuclease digestion and kinase treatment of SINPV DNA. Comparison of EcoRI-digested, kinased (using [ $\gamma$-32P]ATP) SINPV DNA isolated from polyhedra derived from infected larvae by the GIT method (lane 2) and by the GIT method followed by $\mathrm{CsCl}-\mathrm{EtdBr}$ gradient centrifugation (lane 1 ). 
ter homogenization in water, as described above, and filtration through two layers of cheese cloth. The filtrate was centrifuged at $4^{\circ} \mathrm{C}$ for $10 \mathrm{~min}$ at $10000 \times g$ in a Sorvall ${ }^{\circledR}$ RC 5B centrifuge (Du Pont, Wilmington, DE, USA). The polyhedral pellet was washed repeatedly with acetone until the supernatant became colorless, and then it was dried under vacuum.

ECV, pelleted from $12 \mathrm{~mL}$ of infected culture, were suspended in $200 \mu \mathrm{L}$ of $10 \mathrm{mM}$ Tris-HCl/0.1 mM EDTA (Merck, Bombay, India), pH 8.0. To this and to the dried polyhedra $(5 \mathrm{mg})$, $200 \mu \mathrm{L}$ of GIT solution (4.0 M GIT [Fluka Chemie AG, Bucks, Switzerland]; 0.05 M Tris-HCl, pH 7.6; 0.01 M EDTA; 0.148 M 2-mercaptoethanol [Sigma Chemical]; $2 \%$ [wt/vol] $N$-lauroyl sarcosine, sodium salt [Sigma Chemical] containing $0.2 \mathrm{M} \mathrm{NaCl}$ [Merck]) were added to dissolve OV and ECV completely. Equal volumes of $5 \mathrm{M}$ ammonium acetate (Merck) were added to both the solutions, mixed gently and centrifuged in a microcentrifuge at $8000 \mathrm{rpm}$ for $5 \mathrm{~min}$ at room temperature, and the supernatant was collected. The pellets were extracted once by centrifugation with $100 \mu \mathrm{L}$ of $2.0 \mathrm{M}$ GIT containing $2.5 \mathrm{M}$ ammonium acetate as before. The supernatants were pooled and extracted twice with an equal volume of phenol:chloroform:isoamyl alcohol (1:1:1/24) and once with chloroform alone. The viral DNA was finally precipitated with an equal volume of isopropanol at $-70^{\circ} \mathrm{C}$ for $20 \mathrm{~min}$ and was collected by centrifugation at $12000 \mathrm{rpm}$ in a microcentrifuge. The DNA pellet was washed with $70 \%$ ethanol, dried and dissolved in $10 \mathrm{mM}$ Tris- $\mathrm{HCl} / 50 \mathrm{mM} \mathrm{NaCl} / 0.1 \mathrm{mM}$ EDTA, pH 8.0.

Transfection of insect cell line Sf9 with AcNPV DNA was done following the method of Summers and Smith (10). The transfection supernatant was collected $96 \mathrm{~h}$ post-transfection, and the titer of the ECV was determined by end-point dilution (10).

The yield of viral DNA by this method varied from 1.3 to $1.5 \mu \mathrm{g}$ per mg of polyhedra, while 3.7 to $4.0 \mu \mathrm{g}$ of DNA were obtained per $\mathrm{mL}$ of ECV. The absorbance ratio of the DNA at $260 \mathrm{~nm}$ and $280 \mathrm{~nm}$ was found to be 1.8 in all the cases. This high yield facilitates the isolation of recombinant viral DNA directly from $2 \mathrm{~mL}$ of transfection supernatant from 35-mm culture plates. One microgram of viral DNA isolated from ECV by this method, when used for transfection, yields $2.4 \times 10^{8} \mathrm{pfu} / \mathrm{mL}$ (Table 1), which is about 8-fold higher than the titer obtained from transfection done by using DNA isolated with conventional methods (5-7).

Figure 1 shows restriction endonuclease digestion and kinase treatment of baculovirus DNA isolated by this and conventional methods.

Strongly associated basic proteins 
from baculovirus DNA are usually removed by proteinase $\mathrm{K}$ digestion to avoid shearing of the DNA. The high solubility of polyhedra and ECV in GIT solution, and the increased transfection efficiency of DNA isolated by this method, suggest that these chaotropic agents dissociate proteins from DNA without shearing it. Chaotropic agents are also known to remove low molecular weight impurities such as polyamines (1) that are attached to DNA by salt linkage. Ammonium acetate prevents alcohol precipitation of low molecular weight impurities along with DNA.

This method should be very useful for isolating sufficient quantities of pure baculovirus DNA without proteinase $\mathrm{K}$ digestion and dialysis, even from a single infected larva or the virus propagated in a $35-\mathrm{mm}$ plate.

\section{REFERENCES}

1.Bando, H., M. Nakagaki and S. Kawase. 1983. Polyamines in Densonucleosis virus from the silkworm Bombyx mori. J. Invertebr. Pathol. 42:264-266.

2.Bansal, O.B. and R.H. Das. 1989. A simple and rapid method for the isolation of plasmid and lambda phage DNAs. Nucleic Acids Res. 17:10129.

3.Bilimoria, S.L. 1986. Taxonomy and identification of the baculovirus, p. 37-59. In R.R. Granados and B.A. Federici (Eds.), The Biology of Baculoviruses, Vol. 1. CRC Press, Boca Raton.

4.Blissard, G.W. and G.F. Rohrmann. 1990 Baculovirus diversity and molecular biology. Annu. Rev. Entomol. 35:127-155.

5.Holm, C., W. Meeks Wagner, W.L. Fangman and D. Botstein. 1986. A rapid, efficient method for isolating DNA from yeast. Gene 42:169-173.

6.Jeanpierre, M. 1987. A rapid method for the purification of DNA from blood. Nucleic Acids Res. 15:9611.

7.Miller, L.K. and K.P. Dawes. 1978. Restriction endonuclease analysis for the identification of baculovirus pesticides. Appl. Environ. Microbiol. 35:411-421.

8.O'Reilly, D.R., L.K. Miller and V.A. Luckow. 1992. Baculovirus Expression Vectors: A Laboratory Manual. W.H. Freeman \& Co., New York.

9.Smith, I.R.L. and N.E. Crook. 1988. In vitro isolation of baculovirus genotypes. Virology 166:240-244

10.Summers, M.D. and G.E. Smith. 1988. A manual of methods for baculovirus vectors and insect cell culture procedures. Tex. Agric. Exp. Sta. Bull. No. 1555.

Address correspondence to Rakha Hari Das, Genetic Engineering Division, Centre for Biochemical Technology, Mall Road, Delhi 110 007, India. Internet: rhd@cbt. delnet.ernet.in

Received 13 June 1995; accepted 20 September 1995.

R.H. Das, O.B. Bansal, A.K. Behera, Y. Durgaprasad, M. Kumar and A. Bali Centre for Biochemical Technology Delhi, India

\section{Long Primers for RAPD Mapping and Finger- printing of Grape and Pear}

\section{BioTechniques 20:368-371 (March 1996)}

The random-amplified polymorphic DNA (RAPD) technique $(10,12)$ has been widely used in plants for the construction of genetic maps in species such as Arabidopsis (9), bananas (4) and slash pine (7), and for genotype identification and taxonomic studies $(2,5)$. RAPD markers are detected by the use of short oligonucleotides of arbitrary sequence as primers for the amplification of segments of the target genome. Generally, 10-mer primers with $50 \%-80 \% \mathrm{G}+\mathrm{C}$ content are preferred (8). However, complex banding patterns were also generated with primers as short as 5 bases (1). There are few reports on the use of long primers (over 12 bases) $(10,11)$. The potential value of long primers (17-24 bases) for generating RAPD polymorphisms was investigated in this study. We compared the use of both short and long primers in RAPD assays of two plant species: grape and pear.

DNA was extracted from leaves according to the methods of Lodhi et al. (6) for grape and of Doyle and Doyle (3) for pear. RAPD amplification was performed in a reaction volume of 25 $\mu \mathrm{L}$ containing $10 \mathrm{mM}$ Tris- $\mathrm{HCl}(\mathrm{pH}$ 8.0), $50 \mathrm{mM} \mathrm{KCl}, 2 \mathrm{mM} \mathrm{MgCl} 2,0.1 \%$
Triton ${ }^{\circledR} \mathrm{X}-100,120 \mu \mathrm{M}$ each dNTPs, $0.4 \mu \mathrm{M}$ primer, $100-200 \mathrm{ng}$ genomic DNA and 0.5 unit of Taq DNA polymerase. Amplifications were performed on a PTC-100 thermal cycler (MJ Research, Watertown, MA, USA) for (i) 35 cycles of $30 \mathrm{~s}$ at $94^{\circ} \mathrm{C}, 1 \mathrm{~min}$ at $35^{\circ} \mathrm{C}$ and $1 \mathrm{~min} 45 \mathrm{~s}$ at $72^{\circ} \mathrm{C}$, followed by an 8 -min extension at $72^{\circ} \mathrm{C}$ for grape, or (ii) 40 cycles of $1 \mathrm{~min}$ at $94^{\circ} \mathrm{C}, 2 \mathrm{~min}$ at $35^{\circ} \mathrm{C}$ and $2 \mathrm{~min}$ at $72^{\circ} \mathrm{C}$, followed by an 8 -min extension at $72^{\circ} \mathrm{C}$ for pear. Primers (10-mers) were purchased from Operon Technologies (Alameda, CA, USA), National BioSciences (Plymouth, MN, USA), Genosys Biotechnologies (The Woodlands, TX, USA), University of British Columbia (Vancouver, B.C., Canada) and the New York State Center for Advanced Technology in Biotechnology (Cornell University, Ithaca, NY, USA). Long (17-mer to 24-mer) primers were provided by Dr. Sheng-Zhi Pang (Dept. of Plant Pathology, Cornell University, Geneva, NY, USA).

Typical gels displaying the amplification products generated from grape or pear DNA using long primers are shown in Figure 1. In general, long primers generated more DNA fragments, a wider range of DNA fragment sizes

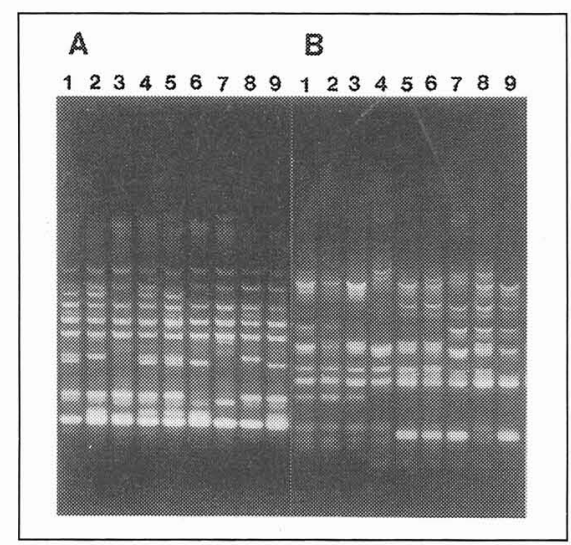

Figure 1. RAPD profiles of grape DNA generated with 21-mer GY169 (CTAAGCTGCTTTTGTTTGAGC) (Panel A) and pear DNA with the 18-mer GY107 (GTTCAGGGCTGTTTATAG) (Panel B). Each panel includes DNA from 9 individuals from the crosses Horizon $x$ Ill. 547-1 (Panel A) and Bartlett x NY10353 (Panel B), respectively. Amplification products were separated by electrophoresis in $2 \%$ agarose gels (1\% agarose $/ 1 \%$ NuSieve ${ }^{\circledR}$ GTG $^{\circledR}$ agarose; FMC BioProducts, Rockland, ME, USA), visualized by staining with ethidium bromide and photographed on a transilluminator using Polaroid Type 55 film (Cambridge, MA, USA). 